\title{
FUNCTIONAL CHARACTERIZATION OF ACETYLATED BRAZIL NUT (Bertholletia excelsa HBK) KERNEL GLOBULIN ${ }^{1}$
}

\author{
Cíntia Maria Pinto RAMOS², Pushkar Singh BORA ${ }^{2, *}$
}

\begin{abstract}
SUMMARY
Defatted Brazil nut kernel flour, a rich source of high quality proteins, is presently being utilized in the formulation of animal feeds. One of the possible ways to improve its utilization for human consumption is through improvement in its functional properties. In the present study, changes in some of the functional properties of Brazil nut kernel globulin were evaluated after acetylation at 58.6, 66.2 and $75.3 \%$ levels. The solubility of acetylated globulin was improved above pH 6.0 but was reduced in the pH range of 3.0-4.0. Water and oil absorption capacity, as well as the viscosity increased with increase in the level of acetylation. Level of modification also influenced the emulsifying capacity: decreased at $\mathrm{pH} 3.0$, but increased at $\mathrm{pH} 7.0$ and 9.0. Highest emulsion activity (approximately 62.2\%) was observed at pH 3.0 followed by $\mathrm{pH} 9.0$ and $\mathrm{pH} 7.0$ and least (about 11.8\%) at pH 5.0. Emulsion stability also followed similar behavior as that of emulsion activity.

Keywords: Brazil nut kernel globulin; chemical modification; acetylation; and functional properties.
\end{abstract}

\section{RESUMO}

CARACTERIZAÇAO FUNCIONAL DAS GLOBULINAS DE AMÊNDOA DE CASTANHA-DO-PARÁ APÓS A ACETILAÇÃO. Farinha desengordurada de amêndoa de castanha-do-Pará, fonte rica de proteína de alta qualidade, vem sendo, atualmente, aproveitada apenas na formulação de ração animal. Uma das possiveis maneiras de melhorar seu aproveitamento para o consumo humano é através do melhoramento de suas propriedades funcionais. No presente trabalho, mudanças em algumas propriedades funcionais da globulina de castanha-do-Pará, após acetilação, aos níveis de 58,6, 66,2 e 75,3\% foram estudadas. A solubilidade da globulina acetilada aumentou acima de $\mathrm{pH}$ 6,0, porém diminuiu na faixa de pH 3,0 a 4,0. As capacidades de absorção de água e de óleo como também a viscosidade, melhoraram com o aumento de grau de acetilação. O grau de modificação também influenciou a capacidade de emulsificação: reduziu em pH 3,0, e aumentou nos pHs 7,0 e 9,0. A máxima atividade de emulsão (aproximadamente 62,2\%) foi observada em pH 3,0 seguida de pH 9,0 e a mínima foi observada $(11,8 \%)$ em pH 5,0. A estabilidade de emulsão também apresentou o comportamento similar à atividade de emulsão.

Palavras-chave: globulina de castanha-do-Pará; modificação química; acetilação; propriedades funcionais.

\section{1 - INTRODUCTION}

The production of Brazil nut kernel is a result of extractive activities and has become one of the principal commercial products from the northern region of Brazil [15]. Major part of its production is exported to other parts of the country as well as to other countries. The broken, damaged or deformed nut kernels are sold at a very low price and are utilized principally by small-scale oil industries. The defatted kernel flour, in spite of being rich source of sulfur containing amino acids [24] is presently used in animal feed formulations. Assessment of the functional properties of Brazil nut kernel globulin may be helpful to evaluate its use in food formulations. However, analyzing the results published by GLORIA \& REGITANO-D'ARCE [6] on the functionality of Brazil nut protein isolate, one could observe that the isolate did not present promising results. Modification of its proteins may possibly lead to an improvement in functional properties. Protein modification by chemical means is being studied in the last two decades. In recent reports, EL-ADAWY [5], LIU \& HUNG [14], GRUNER \& ISMOND [9], KIM, CHOI \& HONG [12], SILVA, BORA \& QUEIROGA

1. Recebido para publicação em 04/04/2003. Aceito para publicação em 29/10/2003 (001098).

2. Departamento de Tecnologia Química e de Alimentos. Universidade Federal da Paraíba, CEP 58059-000, João Pessoa-Pb-Brazil. Telephone: + 5583 216-7576, Fax: 5583 216-7179. Email: Pradesh@uol.com.br. *A quem a correspondência deve ser enviada.
[18], DUA, MAHAJAN \& MAHAJAN [4] to mention a few, have reported the effect of acetic anhydride on the functionality of various protein sources.

Information on fractionation and characterization of Brazil nut kernel proteins [21], methionine rich 2S fraction [24] and N-terminal amino acids of 7S fraction [3] and functional properties of protein isolate and concentrate [6] are available. However, there seems a lack of data on the functionality of chemically modified Brazil nut kernel globulin in scientific literature. Therefore the present work was undertaken to study the effect of different levels of acetylation on some of its functional properties.

\section{2 - MATERIALS AND METHODS}

\section{1 - Material}

Brazil nut (Bertholletia excelsa HBK) kernels were acquired from local market in Belém City in the State of Pará. The dried $\left(50^{\circ} \mathrm{C}\right.$ for $24 \mathrm{hrs}$ ) kernels were ground in a cyclone sample mill with $0.5-\mathrm{mm}$ screen (UD Corporation, Boulder, CO, USA). The flour was defatted with hexane in a Sohxlet apparatus and was used for the preparation of globulin isolate.

\section{2 - Preparation of globulin isolate}

Brazil nut kernel globulin isolate was prepared by the method described by KOYORO \& POWERS [13] with 
minor modification. The defatted flour was extracted with $0.5 \mathrm{M} \mathrm{NaCl}, 50 \mathrm{mM}$ potassium phosphate buffer ( $\mathrm{pH} 7.2$ ) in a ratio of $6 \mathrm{~mL}$ buffer/g of flour. The slurry was stirred for an hour at approximately $15^{\circ} \mathrm{C}$ with magnetic stirrer and centrifuged at $15.000 \mathrm{~g}$ at $4^{\circ} \mathrm{C}$ for $30 \mathrm{~min}$. in a refrigerated centrifuge (Sigma, model 2K15). The residue was extracted two more times and the supernatants were collected. The $\mathrm{pH}$ of the combined supernatant was adjusted to 4.5 and left overnight at $4^{\circ} \mathrm{C}$ to settle globulin precipitate. The resulting suspension was centrifuged again under the same conditions as described above. The pellets were re-extracted with extraction buffer, centrifuged ( $15.000 \mathrm{~g}$ for $15 \mathrm{~min}$ at $4^{\circ} \mathrm{C}$ ) and dialyzed against distilled water at $4^{\circ} \mathrm{C}$ for $48 \mathrm{~h}$ with two changes of water. The pellets (globulin) were recovered by centrifugation and freeze dried.

\section{3 - Acetylation of globulin}

Acetylation of Brazil nut kernel globulin was carried out according to the method described by GRONINGER [8]. The $\mathrm{pH}$ of the globulin solution was adjusted in the range of 8.0 to 8.5 with $1 \mathrm{~N} \mathrm{NaOH}$ and cooled in an ice bath to reduce the temperature to 2 to $5^{\circ} \mathrm{C}$. Acetic anhydride was added to globulin solution at a concentration of $0.1,0.15$ and $0.25 \mathrm{~g} / \mathrm{g}$ of protein. The $\mathrm{pH}$ of the solution was maintained with constant agitation. The reaction was considered to be complete when the $\mathrm{pH}$ of the solution was stabilized. Acetylated globulin were isoelectrically precipitated, centrifuged at $15.000 \mathrm{~g}$ at $5^{\circ} \mathrm{C}$ for $20 \mathrm{~min}$, lyophilized and stored in glass vials at $-20^{\circ} \mathrm{C}$.

The extent of acetylation was measured as colored lysine ninhydrin derivatives produced in dimethylsulfoxide system. The difference in absorbance between dimethylsulfoxide derivatives of native and modified globulin at $580 \mathrm{~nm}$ was used as an index of the extent of chemical modification [1].

Protein content was determined by biuret method [7]. Bovine serum albumin (Sigma) was used as a standard for calibration.

\section{4 - Functional properties}

\subsection{1 - Solubility}

One hundred milligram lyophilized native and acetylated globulin were suspended in $20 \mathrm{~mL}$ distilled water and the $\mathrm{pH}$ of the suspensions was adjusted from 2.0 to 12.0 using $0.1 \mathrm{~N} \mathrm{HCl}$ or $\mathrm{NaOH}$ solution. The suspensions were agitated with a magnetic stirrer for $30 \mathrm{~min}$ at room temperature; the $\mathrm{pH}$ was checked and adjusted, then centrifuged at $4.300 \mathrm{~g}$ for $30 \mathrm{~min}$. The quantity of protein dissolved in supernatant was determined.

\subsection{2 - Water and oil absorption}

Water and oil absorption were determined according to the method described by BEUCHAT [2]. Five hundredmilligram samples were dispersed in 5-mL distilled water or refined soy oil (Soya brand, Bunge alimentos S.A) and placed in $10 \mathrm{~mL}$ graduated centrifuge tubes. The dispersions were stirred occasionally with a glass rod. After a holding period of 30min, dispersions were centrifuged at $3.000 \mathrm{~g}$ for $10 \mathrm{~min}$ and the volume of the released fluid was measured. Water and oil absorption was expressed as $\mathrm{ml}$ of water or oil retained per $\mathrm{g}$ of globulin.

\subsection{3 - Relative viscosity}

Relative viscosity of 1,2 and $3 \%$ native and acetylated globulin solutions in $0.5 \mathrm{M} \mathrm{NaCl}, 50 \mathrm{mM}$ potassium phosphate buffer, $\mathrm{pH} 7.2$ at room temperature $\left(29^{\circ} \mathrm{C}\right)$ was determined before and after heating to $90^{\circ} \mathrm{C}$ for $15 \mathrm{~min}$ in an Ostwald viscometer.

\subsection{4 - Emulsifying properties}

Emulsifying capacity was determined using the methods of KATO et al. [11] and HUNG \& ZAYAS [10]. Native and acetylated globulin dispersions $(1.0 \mathrm{mg} / \mathrm{mL})$ were adjusted to $\mathrm{pH}$ 3.0, 5.0, 7.0 and 9.0. Fifty-ml volumes of dispersions were transferred to the glass cup of emulsification apparatus [18] containing at its bottom a pair of electrodes connected to a galvanometer. The dispersions were agitated at 10.000rpm with a constant flux $(22 \mathrm{~mL} / \mathrm{min})$ of refined soy oil. The quantity of oil necessary for the inversion of emulsion (characterized by a sudden drop in electric current) was measured. The result was expressed as $\mathrm{mL}$ oil/100mg globulin.

Emulsifying activity and stability of globulin were determined by the method of YASUMATSU, et al. [23]. Twenty $\mathrm{ml}$ portions of globulin solution $(25 \mathrm{mg} / \mathrm{mL})$ of varying $\mathrm{pH}(3.0,5.0,7.0$ and 9.0) were homogenized with $20 \mathrm{~mL}$ refined soy oil at a speed of 5 in a scale varying from 1 to 10 of Omni Sorvall mixer, for $1 \mathrm{~min}$. The emulsions were centrifuged at $1.100 \mathrm{~g}$ for $5 \mathrm{~min}$. The height of emulsified layer and that of the total contents in the tube was measured. The emulsifying activity was calculated as:

$\frac{\text { Height of emulsified layer in the tube }}{\text { Height of the total contents in the tube }}$

To determine the emulsion stability, the emulsions were heated at $80^{\circ} \mathrm{C}$ for $30 \mathrm{~min}$ and centrifuged again. Emulsion stability was calculated using the same formula as above.

Five repetitions were carried out for the determination of functional properties except that of solubility for which three repetitions were made.

\section{5 - Statistical analysis}

Statistical analysis of the results was done with Statistics for Windows 5.0 [20] and the t- test was used to determine significance of differences between means. Trends were considered significant when means of compared sets differed at $\mathrm{p}>0.05$. 


\section{3 - RESULTS AND DISCUSSION}

The extent of modification expressed as percentage of acetylated e-amino groups of lysine of Brazil nut globulin obtained with different concentrations of acetic anhydride was as follows:

\begin{tabular}{cc}
\hline Acetic anhydride (g/g globulin) & A \% Acetylation of amino groups of lysine \\
\hline 0.00 & 0.0 \\
0.10 & 58.6 \\
0.15 & 66.2 \\
0.25 & 75.3 \\
\hline
\end{tabular}

The solubility profile of native and acetylated Brazil nut kernel globulin in the $\mathrm{pH}$ range of 2.0 to 12.0 is shown in Figure 1. The isoelectric $\mathrm{pH}$ of the native globulin was at 5.0 which is in agreement with the isoelectric $\mathrm{pH}$ (4.0 to 5.0) of most of the plant proteins [22], while for acetylated globulin independent of their level of acetylation, it was at $\mathrm{pH}$ 4.0. The shift reflects an increase in the net negative charge as a result of replacing the positively charged amino groups of lysine with neutrally charged hydrophobic acetyl groups. According to the SHEEN [7], SITOHY, SHAROBEEM \& ABDEL-GHANI [10], DUA et al. [4] AND GRUENER \& ISMOND [9] acylated proteins exhibit a shift in their isoelectric $\mathrm{pH}$ thus resulting in an increased solubility at neutral to alkaline $\mathrm{pH}$. In comparison to native globulin, acetylated globulin in our study have also shown enhanced solubility at $\mathrm{pH}$ above 6.0 but was greatly reduced at $\mathrm{pH} 3.0$ to 4.0. Among different acetylated globulin samples, very little difference in solubility was observed.

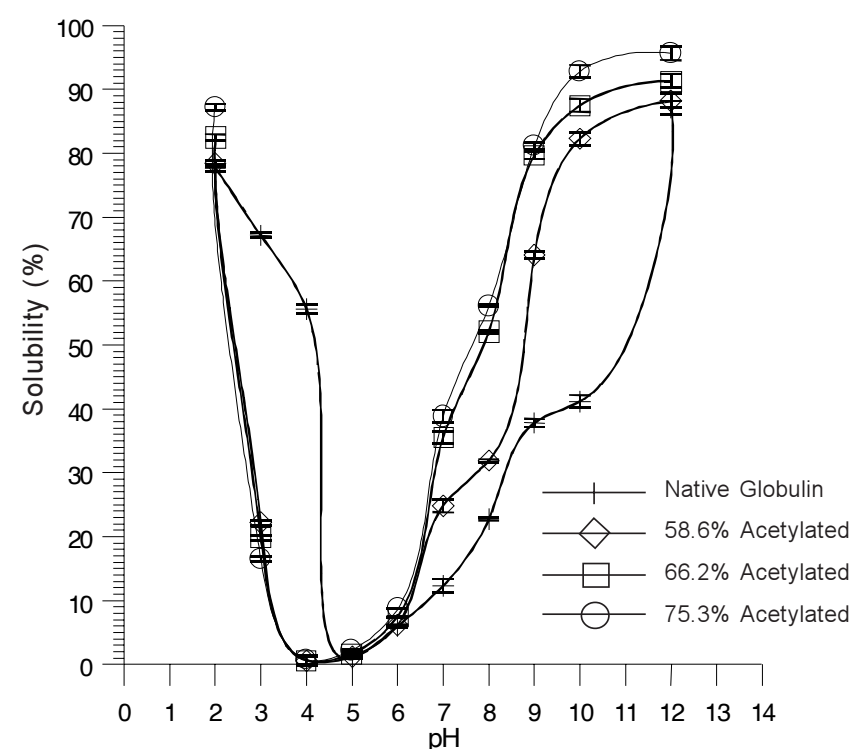

FIGURE 1. Solubility of native and acetylated brazil nut kernel globulin as a function of $\mathrm{pH}$

The data on the water absorption capacities of acetylated globulin is shown in Table 1. Relative to native globulin, there was a marked improvement (approximately 70 to $85 \%$ ) in water absorption capacity of acetylated globulin. Statistically, significant difference at the level of $p>0.05$ among globulin samples with increase in the level of acetylation was observed. Similarly, improvement in the water absorption capacity of proteins by acetylation has also been reported for mung bean [5], rapeseed [4] and oat protein isolates [16]. SHEEN [17] and PONNAMPALAM et al. [16] also observed an increase in water absorption with increase in the extent acetylation for tobacco leaf and oat proteins.

Acetylation also improved oil absorption capacity of Brazil nut kernel globulin. Similar to water absorption capacity, significant difference in the oil absorption capacity among samples of different level of acetylation was observed. The oil absorption of 58.6, 66.2 and 75.3\% acetylated globulin samples increased about 74.6, 81.5 and $93.8 \%$ in comparison to native globulin. EL-ADAWY [5], GRUENER \& ISMOND [9], DUA et al. [4] and PONNAMPALAM et al. [16] have reported improvement in oil absorption capacity of various acetylated protein isolates. However, contrary to our study with acetylated Brazil nut kernel globulin, DUA et al. [4] and PONNAMPALAM et al. [16] observed decrease in oil absorption with increase in the level of acetylation.

The relative viscosity of acetylated Brazil nut globulin is also shown in Table 1. Significant difference among the relative viscosity of different acetylated samples was observed. The relative viscosity of the acetylated Brazil nut kernel globulin solutions increased with the level of acetylation. For 58.6, 66.2 and $75.3 \%$ acetylated globulin samples, in most of the cases, there was a progressive increase in relative viscosity of 1.0, 2.0 and 3.0\% solutions at room temperature before and after heating at $90^{\circ} \mathrm{C}$ for $15 \mathrm{~min}$. In comparison to unheated samples, significant increase in relative viscosity was observed in all heated samples.

Emulsifying properties of native and modified Brazil nut kernel globulin as a function of $\mathrm{pH}$ is shown in Table 2. Emulsifying capacity of the samples varied with the $\mathrm{pH}$ as well as with the degree of acetylation. At pH 3.0 native globulin, due to its better solubility than acetylated globulin, possessed higher emulsifying capacity. However, the extent of acetylation greatly influenced emulsifying capacity, higher the extent of acetylation, lower was the emulsifying capacity. At $\mathrm{pH}$ 5.0, all samples presented minimum but almost similar emulsifying capacities. Contrary to $\mathrm{pH} 3.0$, emulsifying capacity of acetylated globulin improved at pH 7.0 and 9.0, which increased with the degree of acetylation. No statistical difference was observed in emulsion activity and stability of acetylated globulin, independent of their degree of acetylation. However, with respect to $\mathrm{pH}$, best emulsion activity and stability was observed at $\mathrm{pH}$ 3.0. Difference in emulsifying properties of acetylated proteins has appeared in scientific literature. GRUENER \& ISMOND [9] and PONNAMPALAM et al. [16] reported an increase in emulsion activity and stability, while according to DUA et al. [4] acetylation adversely affected emulsifying properties of rapeseed proteins. 
TABLE 1. Water and oil absorption capacities, and viscosity of native and acetylated Brazil nut kernel globulins

\begin{tabular}{|c|c|c|c|c|c|}
\hline \multirow[b]{2}{*}{ Sample } & \multirow{2}{*}{$\begin{array}{c}\text { WAC } \\
(\mathrm{ml} / \mathrm{g} \\
\text { protein) }\end{array}$} & \multicolumn{4}{|c|}{ Relative viscosity of globulin solution at room temperature $\left(29^{\circ} \mathrm{C}\right)$} \\
\hline & & $\begin{array}{c}(\mathrm{ml} / \mathrm{g} \\
\text { protein) }\end{array}$ & Before $\mathrm{h}$ & $\begin{array}{l}\text { neating After heating at } 90^{\circ} \mathrm{C} \text { for } 15 \mathrm{~min} \\
(1 \%)(3 \%)(5 \%)(1 \%)(3 \%)(5 \%)\end{array}$ & \\
\hline Native globulin & $1.96 \pm 0.04 \mathrm{a}$ & $1.47 \pm 0.02$ a $1.05 \pm 0.02$ a $A$ & $1.17 \pm 0.03$ a B & $1.32 \pm 0.03$ a C $1.11 \pm 0.03$ a B $1.18 \pm 0.02$ a B & $1.51 \pm 0.03$ a D \\
\hline $\begin{array}{c}58.6 \% \text { acetylated } \\
\text { globulin }\end{array}$ & $3.34 \pm 0.02 b$ & $2.55 \pm 0.04$ b $1.25 \pm 0.02$ b A & $1.42 \pm 0.03 \mathrm{~b} \mathrm{~B}$ & $1.74 \pm 0.03$ b C $1.37 \pm 0.04$ b B $1.53 \pm 0.05$ b D & $1.86 \pm 0.04 \mathrm{~b} \mathrm{E}$ \\
\hline $\begin{array}{c}66.2 \% \text { acetylated } \\
\text { globulin }\end{array}$ & $3.51 \pm 0.01 \mathrm{c}$ & $2.65 \pm 0.03$ b $1.32 \pm 0.03$ c A & $1.58 \pm 0.04 \mathrm{c} \mathrm{B}$ & $1.91 \pm 0.02$ c C $1.59 \pm 0.05$ c B $1.84 \pm 0.04$ c D & $2.01 \pm 0.03 \mathrm{c} \mathrm{E}$ \\
\hline $\begin{array}{c}75.3 \% \text { acetylated } \\
\text { globulin }\end{array}$ & $3.65 \pm 0.01 d$ & $2.83 \pm 0.05 \mathrm{c} \quad 1.55 \pm 0.03 \mathrm{~d} A$ & $1.84 \pm 0.04 \mathrm{~d} \mathrm{~B}$ & $1.99 \pm 0.04 \mathrm{~d} C \quad 1.86 \pm 0.02 \mathrm{~d} \mathrm{~B} 2.06 \pm 0.05 \mathrm{~d} C D$ & $2.12 \pm 0.04 \mathrm{~d} D$ \\
\hline
\end{tabular}

Mean in each column and row followed by different (small and capital letters, respectively) were significantly different ( $\mathrm{p}>0.05$ level)

WAC - Water absorption capacity, OAC - Oil absorption capacity

TABLE 2. Emulsifying properties of native and acetylated Brazil nut Kernel globulin

\begin{tabular}{|c|c|c|c|c|c|}
\hline $\begin{array}{l}\text { Emulsifying } \\
\text { Property }\end{array}$ & $\begin{array}{l}\text { Globulin } \\
\text { Samples }\end{array}$ & $\mathrm{pH} 3.0$ & PH 5.0 & $\mathrm{pH} 7.0$ & $\mathrm{pH} 9.0$ \\
\hline \multirow{4}{*}{$\begin{array}{l}\text { Emulsifying } \\
\text { Capacity } \\
\text { (ml oil/100 } \\
\text { mg protein) }\end{array}$} & $\begin{array}{l}\text { Native } \\
\text { Globulin } \\
58.6 \%\end{array}$ & $93.9 \pm 1.2$ a A & $38.8 \pm 0.8$ a B & $48.4 \pm 1.0$ a C & $52.4 \pm 1.2$ a D \\
\hline & $\begin{array}{l}\text { acetylated } \\
\text { globulin }\end{array}$ & $86.5 \pm 0.9 \mathrm{~b} \mathrm{~A}$ & $38.8 \pm 1.0$ a B & $66.7 \pm 1.1 \mathrm{~b} \mathrm{C}$ & $96.0 \pm 1.2$ b D \\
\hline & $\begin{array}{c}66.2 \% \\
\text { acetylated } \\
\text { globulin }\end{array}$ & $74.4 \pm 1.0 \mathrm{c} \mathrm{A}$ & $39.6 \pm 0.9$ a B & $74.2 \pm 1.2 \mathrm{c} \mathrm{A}$ & $99.5 \pm 1.6$ c C \\
\hline & $\begin{array}{l}75.3 \% \\
\text { acetylated } \\
\text { globulin }\end{array}$ & $66.7 \pm 1.3 \mathrm{~d} A$ & $41.4 \pm 0.2$ b B & $78.6 \pm 1.5 \mathrm{~d} \mathrm{C}$ & $106.5 \pm 1.4 \mathrm{~d} \mathrm{D}$ \\
\hline \multirow{4}{*}{$\begin{array}{c}\text { Emulsion } \\
\text { Activity } \\
(\%)\end{array}$} & $\begin{array}{l}\text { Native } \\
\text { Globulin } \\
58.6 \%\end{array}$ & $63.8 \pm 1.4$ a $A$ & $11.8 \pm 0.9$ a B & $51.5 \pm 0.9$ a C & $53.2 \pm 1.2 \mathrm{a} \mathrm{C}$ \\
\hline & $\begin{array}{c}\text { acetylated } \\
\text { globulin }\end{array}$ & $62.3 \pm 1.1$ a A & $11.8 \pm 1.0$ a B & $51.9 \pm 1.6$ a C & $54.0 \pm 1.3$ a C \\
\hline & $\begin{array}{l}\text { acetylated } \\
\text { globulin } \\
75.3 \%\end{array}$ & $62.3 \pm 0.8$ a A & $11.7 \pm 0.9$ a B & $52.0 \pm 1.1$ a C & $54.5 \pm 1.1$ a D \\
\hline & $\begin{array}{l}\text { acetylated } \\
\text { globulin }\end{array}$ & $62.2 \pm 1.1$ a $A$ & $11.9 \pm 1.1$ a B & $52.1 \pm 1.2$ a C & $54.8 \pm 1.0$ a D \\
\hline \multirow{4}{*}{$\begin{array}{c}\text { Emulsion } \\
\text { Stability } \\
(\%)\end{array}$} & $\begin{array}{l}\text { Native } \\
\text { Globulin } \\
58.6 \%\end{array}$ & $62.8 \pm 1.4 \mathrm{a} \mathrm{A}$ & $11.7 \pm 0.9$ a B & $51.2 \pm 1.0$ a C & $52.6 \pm 1.1 \mathrm{a} \mathrm{C}$ \\
\hline & $\begin{array}{l}\text { acetylated } \\
\text { globulin }\end{array}$ & $62.2 \pm 1.2$ a A & $11.7 \pm 0.8$ a B & $51.0 \pm 1.0$ a C & $52.9 \pm 1.2$ a C \\
\hline & $\begin{array}{c}66.2 \% \\
\text { acetylated } \\
\text { globulin } \\
75.3 \%\end{array}$ & $62.2 \pm 0.9$ a A & $11.8 \pm 0.8$ a B & $51.3 \pm 0.8$ a C & $54.5 \pm 1.0$ a D \\
\hline & $\begin{array}{l}\text { acetylated } \\
\text { globulin }\end{array}$ & $62.2 \pm 0.9$ a $A$ & $11.8 \pm 1.0$ a $B$ & $51.5 \pm 1.1$ a C & $54.6 \pm 1.1$ a D \\
\hline
\end{tabular}

\section{4 - CONCLUSIONS}

Acetylation modified the functional properties of the Brazil nut kernel globulin. In comparison with the native globulin, the solubility was appreciably enhanced above $\mathrm{pH}$ 6.0, while the solubility was decreased at $\mathrm{pH}$ range of 3.0 to 4.0. Acetylated globulin showed a shift in their isoelectric $\mathrm{pH}$ from 5.0 of that of native globulin to 4.0. The solubility behavior of acetylated globulin suggests their use in the formulation of high protein drinks with their $\mathrm{pH}$ near neutrality. Water and oil absorption capacity of acetylated globulin was also improved showing their potential as an ingredient in the formulation of sausage type of products. Small increase in relative viscosity of modified globulin also suggestive of their use in the formulation of high protein soups. High emulsifying capacity, emulsion activity and stability at $\mathrm{pH}$ around 7.0 to 9.0 is also indicative of the use of Brazil nut kernel acetylated globulin as an emulsifying agent.

\section{5 - REFERENCES}

[1] BECKWITH, A. C., BONDER, R. F. \& CIEGLER, A. Direct estimation of lysine in corn meal by the ninhydrin color reaction. J. Agric. Food Chem., v. 23, p. 194196, 1975.

[2] BEUCHAT, I. R. Functional and electrophoretic characteristics of succinylated peanut flour proteins. J. Agric.Food Chem., v. 25, p. 258-263, 1977.

[3] CAI, J. \& WELLER, D. L. N-Terminal amino acids of Brazil nut 7s protein. J. Food Biochem, v. 19, p. 4349, 1995.

[4] DUA, S., MAHAJAN, A. \& MAHAJAN, A. Improvement in functional properties of rapeseed (Brassica campestris var. Toria) preparations by chemical modification. J. Agic. Food Chem., v. 44, n. 3, p. 706-710, 1996.

[5] EL-ADAWY, T. A. Functional properties and nutritional quality of acetylated and succinylated mung bean protein isolate. Food Chem., v. 70, n. 1, p. 83-91, 2000.

[6] GLORIA, M. M. \& REGITANO-D'ARCE, M.A B. Concentrado e isolado proteico de torta de castanha-do-Pará: Obtenção e caracterização química e funcional. Ciên. Tecnol. Aliment., n. 20, p. 1-13, 2000.

[7] GORNALl, A. G; BORDAWILL, C. S. \& DAVID, M. M. The determination of protein by the biuret reaction. $\mathbf{J}$. Biol. Chem, v. 177, p. 751-780, 1949.

[8] GRONingeR, H. S. Preparation and properties of succinylated fish myofibrillar protein. J. Agric. Food Chem., v. 21, p. 978-981, 1973.

[9] GRUENER, L. \& ISMOND, M. A. H. Effect of acetylation and succinylation on the functional properties of the canola 12S globulin. Food Chem., v. 60, n. 4, p. 513$520,1997$. 
[10] HUNG, S. C. \& ZAYAS, J. F. Emulsifying capacity and emulsion stability of milk proteins and corn germ protein flour. J. Food Sci., v. 56, n. 5, p. 1216-1219, 1991

[11] KATO, A., TAKAHASHI, A., MATSUDOMI, N. \& KOBAYASHI, K. Determination of emulsifying properties of some proteins by conductivity measurements. J. Food Sci., v. 50, n. 1, p. 50-62, 1985.

[12] KIM I. S; CHOI, J. H. \& HONG, J. H. Changes in functional properties of casein by different chemical modification. J. Food Sci. Nutr., v. 2, n. 1, p. 17-22, 1997.

[13] KOYORO, H. \& POWERS, J. R. Functional properties of pea globulin fractions. Cereal Chem; v. 64, p. 97$101,1987$.

[14] LIU, L.H. \& HUNG, T. V. Functional Properties of acetylated chickpea proteins. J. Food Sci., v. 63, p. 331-337, 1998.

[15] OHASHI, S. T; DANIEL, O. \& COSTA, L. G. S. A Castanha do Brasil. Bertholettia excelsa H B K Belém, FCAP. Serviço de Dcumentação e Informação, 1995, 17 p.

[16] PONNAMPALAM, R., GOUlet, G., AMiOT, J., CHAMBERLAND, B. \& BRISSON, G. J. Some functional properties of acetylated and succinylated oat protein concentrates and a blend of succinylated oat protein and whey protein concentrates. Food Chem., v. 29, p. 109-118, 1988.

[17] SHEEN, S. J. Effect of succinylation on molecular and functional properties of soluble tobacco leaf proteins. J. Agric. Food Chem., v. 39, n. 6, p. 1070-1074, 1991.

[18] SILVA, J. B; BORA, P. S. \& QUEIROGA NETO, V. Caraterização de propriedades funcionais do isolado proteíco de sementes de algaroba (Prospis juliflora D.C.) modificado por acetilação. Cienc. Tecnol Aliment., v. 17, n. 3, p. 263-269, 1997.

[19] SITOHY, M. Z., SHAROBEEM, S. F. \& ABDEL-GHANY, A. A. Functional properties of some succinylated protein preparations. Acta Alimentaria, v. 21, n. 1, p. 31-38, 1992.

[20] STATISTICS FOR WINDOWS (A Complete Program Manual). Stat. Soft. Inc., Tulsa, Ok, USA, 1995.

[21] SUN, SAMUAL S. M., LEUNG, F. W. \& TOMIC, J. C. Brazil nut (Bertholletia excelsa H.B.K.) proteins: Fractionation, Composition and Identification of a sulfur-rich protein. J. Agric. Food Chem, v. 35, p. 232-235, 1987.

[22] VANI, B.\& ZAYAS, J. F. Wheat germ protein flour solubility and water retention. J. Food Sci., v. 60, p. 845-848, 1995.

[23] YASUMATSU, K., SAWADA, L, MORITAKA, S., MISAKI, N., TODA, J., WADA, T. \& ISHII, K. Whipping and emulsifying properties of soybean products. Biol. Chem., v. 36, p. 719-727, 1972.

[24] ZUO, W-N. \& SUN, SAMUAL S. M. Purification and Characterization of the Methionine Rich 2S Seed Proteins from the Brazil Nut Family (Lecythidaceae). J. Agric. Food Chem., v. 44, p. 1206-1210, 1996.

\section{6 - ACKNOWLEDGEMENT}

One of the authors, Ramos, C. M. P; thanks Conselho Nacional de Pesquisa e Desenvolvimento Tecnológico (CNPq), Brazil for financial Assistance during postgraduate study. 